\title{
Ensino de História e o direito à vida
}

\section{Teaching History and the Right to Life}

Iniciamos o ano de 2020 com um novo desafio para a Revista História Hoje: a criação da política editorial de chamadas públicas de dossiês. Uma tarefa assumida com determinação e compromisso por nosso Conselho Editorial e Consultivo, congregando professores de diversas instituições de ensino nesse imenso país de contradições, histórias e dilemas. Ao longo dos meses de março e abril, recebemos mais de dez propostas de dossiês com temáticas sobre meio ambiente, linguagens, diversidades, minorias, sensibilidades, formação e prática docente e direitos humanos. Não foi um processo fácil selecionar entre tantas preciosidades, escritos tão plurais e originais, apenas quatro propostas.

Não sabemos ao certo se tivemos êxito ou não nessa arte nada poética de quantificar expectativas, concepções de mundo e demandas do ensino de História na contemporaneidade. Diante do impiedoso movimento do ponteiro do relógio, havia um prazo a ser cumprido. Mensagens eletrônicas, recados nos aplicativos e telefonemas estabeleciam a conexão necessária para a definição dos dossiês que seriam contemplados.

De alguma forma, a escolha implica deixar outras histórias no caminho. Não sei se por apego, desejo ilusório de totalidade ou incapacidade mesmo, decidimos os dossiês contemplados, mas com uma imensa dívida e gratidão a todos e todas que apresentaram-se diante de nossa comunidade com suas respectivas propostas. Quando observamos esse conjunto de temáticas instigantes, densas e provocativas, há o sentimento de que o futuro é de utopias e esperanças, mesmo diante das maquinarias autoritárias que rondam lá fora... É gratificante vislumbrar um trabalho elaborado de tessitura das peças que irão compor cada mosaico (dossiê), no fazer artesanal das mãos de professores e professoras da Educação Básica, dos institutos e escolas técnicas e universidades.

E para inaugurar essa temporada de dossiês para o biênio 2020-2021 apresentamos uma obra de arte, da sensibilidade de pessoas como Raquel Alvarenga Sena Venera e Felipe Rodrigues da Silva. O Dossiê Narrativas, Direitos Humanos e Formação de Professores de História é um chamado para as nossas urgências visíveis e invisíveis de um mundo que pede cuidado com a vida, novas utopias em meio à desertificação da existência e pausa para entender que não tem sentido correr sem saber qual destino a seguir. Precisamos aprender a romper o fluxo automático e desumanizado da vida cotidiana, da educa- 
ção tecnicista e esvaziada de sentidos, de professores de História sem história, de narrativas ditas e não ouvidas e do esquecimento dos direitos humanos como um patrimônio coletivo global, universal sem ser totalizante. Não há privilégios nos direitos, pois, se assim for, tornam-se moedas de troca, demarcando quem deve viver, sobreviver ou perecer. A educação em e para os direitos humanos no ensino de História não pode ser apenas uma carta de intenções, um projeto de futuro, e sim um convite diário ao enfrentamento de todos os desejos de aniquilação das diferenças - o que implica nosso fim melancólico neste planeta. O conjunto de artigos que compõem esse Dossiê é um chamado de luta, ação e teimosia para nós, professores e professoras de História.

Além do Dossiê, este número da Revista História Hoje apresenta textos, em suas diferentes seções, que lançam percepções da pesquisa e práticas no ensino de História. Desde meados de 2019, temos recebidos artigos, entrevistas e resenhas numa proporção sempre crescente, o que tem demandado muito trabalho para nossos avaliadores e avaliadoras ad hoc e conselheiros e conselheiras.

$\mathrm{O}$ ano de 2020 nos provoca uma fratura, uma quebra no tempo do relógio e a sensação de perda de sentido. Um vírus de incalculável letalidade associado ao discurso do ódio cruzou nossos caminhos, rompeu laços e ceifou sonhos em uma lista de ausências sentidas que a cada dia tem nomes, rostos e significados familiares. São partidas sem despedidas, pesando a solidão de quem se vai e dos que ficam... Ou aguardam a contagem dos dias. E fica a questão incômoda nesse isolamento: o que estamos fazendo de nós mesmos?

Não poderíamos abrir este número sem lembrar de tantas vidas que entraram nas barcas para a passagem, deixando saudades, sofrimentos e muitas dúvidas nessa pandemia... Não há moedas suficientes, fortunas incalculáveis, que consigam pagar os barqueiros nessas dolorosas travessias...

Dedicamos este número à memória de todas as vítimas da pandemia da Covid-19 e seus familiares enlutados. A todos e todas profissionais da saúde, assistentes sociais, cientistas, pesquisadores e pesquisadoras, voluntários e voluntárias na linha de frente em defesa da vida, registramos nossa gratidão e respeito. Jamais esqueceremos... Jamais esqueceremos... Histórias sobre esses tempos serão escritas e ensinadas, porque iremos sobreviver, e todos e todas vocês estarão lá... Uma imensa multidão de empatia e humanidade...

Renilson Rosa Ribeiro Editor 